\title{
Richwood, West Virginia after the 2016 Flood: Place, Devastation, and Hope in an Appalachian Community
}

Christine Elizabeth Witt

West Virginia University, cwitt4@mix.wvu.edu

Follow this and additional works at: https://researchrepository.wvu.edu/etd

Part of the Human Geography Commons

\section{Recommended Citation}

Witt, Christine Elizabeth, "Richwood, West Virginia after the 2016 Flood: Place, Devastation, and Hope in an Appalachian Community" (2019). Graduate Theses, Dissertations, and Problem Reports. 7415. https://researchrepository.wvu.edu/etd/7415

This Thesis is protected by copyright and/or related rights. It has been brought to you by the The Research Repository @ WVU with permission from the rights-holder(s). You are free to use this Thesis in any way that is permitted by the copyright and related rights legislation that applies to your use. For other uses you must obtain permission from the rights-holder(s) directly, unless additional rights are indicated by a Creative Commons license in the record and/ or on the work itself. This Thesis has been accepted for inclusion in WVU Graduate Theses, Dissertations, and Problem Reports collection by an authorized administrator of The Research Repository @ WVU. For more information, please contact researchrepository@mail.wvu.edu. 


\title{
Richwood, West Virginia after the 2016 Flood: Place, Devastation, and Hope in an Appalachian Community
}

\author{
Christine Elizabeth Witt
}

Thesis submitted to the Eberly College at West Virginia University in partial fulfillment of the requirements for the degree of

Master of Arts in

Geography

\author{
María A. Pérez, Ph.D., Chair \\ Trevor Harris, Ph.D. \\ Daniel Renfrew, Ph.D. \\ Department of Geology and Geography \\ Morgantown, West Virginia \\ 2018
}

Keywords: community, resilience, hope, emotional geographies, disaster, Appalachia, politics, school consolidation

Copyright 2018 Christine Elizabeth Witt 


\title{
ABSTRACT \\ Richwood, West Virginia after the 2016 Flood: Place, Devastation, and Hope in an Appalachian Community
}

\author{
Christine Elizabeth Witt
}

How does a community cope with a crisis that threatens its identity or even its existence? This is the question facing the town of Richwood, West Virginia, after a devastating flood that impacted much of the town in 2016. Some of the consequences of the 2016 flood were the loss of the high school building, followed by difficulties receiving the FEMA (Federal Emergency Management Agency) money to rebuild the school, and a loss of additional FEMA money for other critical issues due to alleged corruption. How do community residents cope emotionally with devastation? How do they understand the causes of their plight? And, more importantly, how do they make sense of the future, and who does it include? Building on work in emotional geographies, everyday politics, and anthropology of disaster, I examine these questions with a mixed-method approach including ethnography and interviews. I show how the themes of place, politics, and hope in how Richwood residents define community and imagine its future are interrelated. Central to understanding these themes is a focus on the material and symbolic qualities of particular places, such as a school, to rural livelihoods. These places remain a key aspect of people's lives and sense of future even after their physical destruction. This project contributes to the study of small communities within the Appalachian region or anywhere else where residents face the daunting task of rebuilding after a crisis. 


\section{Table of Contents}

I. Introduction

II. Background on Richwood 2

A. Historical Background _ 2

B. The 2016 Flood__ 4

C. After the Flood: Richwood High School's Uncertain Future

D. Scenes of Life in Richwood Today___ 7

III. Literature Review__ 10

A. The Role of Place in Community _ 10

B. Precarity in Appalachia and the Politics of Community___ 14

C. On Crises and Devastation__ 17

D. Emotional Geographies of Hope__ 21

IV. Methods__ 25

A. Preliminary Research _ 25

B. Positionality_ 26

C. Case Selection _ 27

D. Interviewing/Sampling _ 27

E. Research Locations _ 29

V. Results and Discussion

A. "The School as the Heart of the Community" 31

B. Precarity in Appalachia and the Politics of Community 37

C. On Devastation and Hope 41

VI. Conclusions 46

VII. References 50

IIX. Appendices 55 


\section{Introduction}

How does a community cope with a crisis that threatens its identity or even its existence? This is the question facing the town of Richwood, West Virginia, after a devastating flood that impacted much of the town in 2016. Some of the consequences of the 2016 flood were the loss of the high school building, followed by difficulties receiving the FEMA (Federal Emergency Management Agency) money to rebuild the school, and a loss of additional FEMA money for other critical issues due to alleged corruption. While questions of resources are critical, they must be understood alongside a broader set of concerns. This is true not just in Richwood but in any community facing the aftermath of devastation. How do community residents cope emotionally with devastation? How do they understand the causes of their plight? And, more importantly, how do they make sense of the future, and who does it include? The aim of this project is answer these questions in the context of Richwood, West Virginia. Building on work in emotional geographies, everyday politics, and anthropology of disaster, I examine these questions with a mixed-method approach including ethnography and interviews. I show how the themes of place, politics, and hope in how Richwood residents define community and imagine its future are interrelated. Central to understanding these themes is a focus on the material and symbolic qualities of particular places, such as a school, to rural livelihoods. These places remain a key aspect of people's lives and sense of future even after their physical destruction. This project contributes to the study of small communities within the Appalachian region or anywhere else where residents face the daunting task of rebuilding after a crisis. 


\section{Background on Richwood}

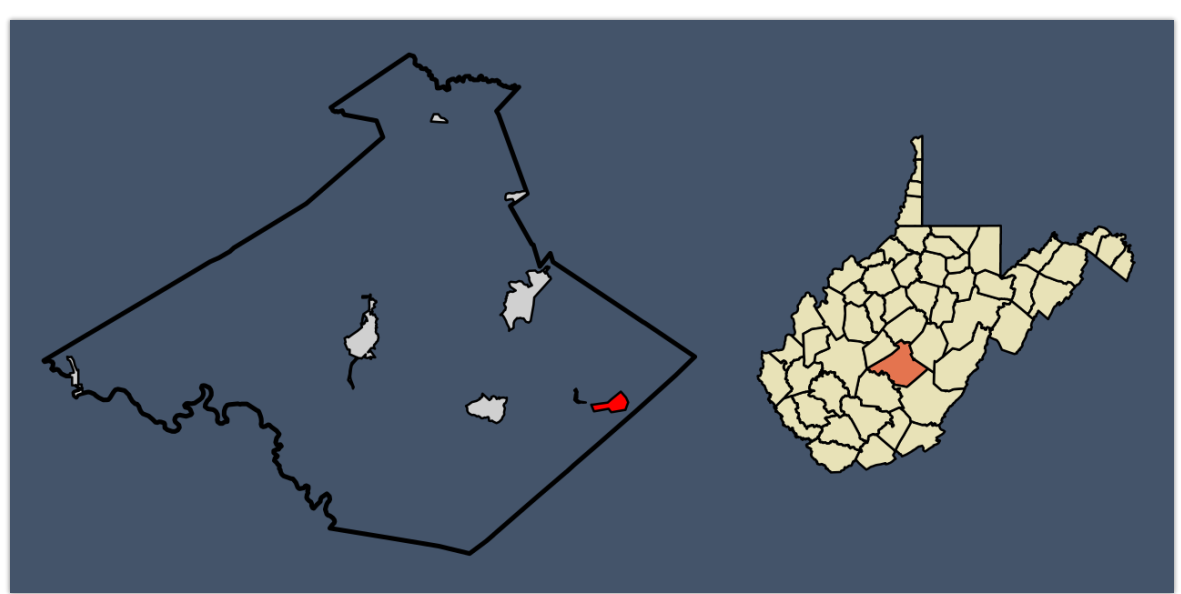

Wikipedia.org

Figure 1

\section{A. Historical Background}

Richwood is located in Nicholas County, West Virginia (Figure 1). This county is in the southeastern part of the state. The town of Richwood is nestled in the Monongahela National Forest, not far from the Cranberry Wildlife Management Area. The town has long been known for its timber industry (the high school's mascot is the Lumberjack). Many residents depended on this industry for employment.

While the town of Richwood was incorporated in 1901, I want to acknowledge the likely presence, prior to settler colonialism, of the following nations in this region of eastern North America: Iroquoian, Algonquian, and Siouan (Kercheval et al. 1833). ${ }^{1}$ There are very few historical references to the town of Richwood. The following is a summary from a timeline printed in educational material collated by the City of Richwood Historic District. When Richwood was founded 1901, it was called Cherry Tree Bottoms. Because of the abundance of

\footnotetext{
${ }^{1}$ I thank Kristen de Graauw for providing this historical reference.
} 
timber in the region, the Cherry River Boom and Lumber Company was founded in 1901. Other prominent businesses and employers in Richwood were the J.B. Dodge Clothespin Factory, the Wm. F. Mosser Tanning Company, the Sherwood Manufacturing Company, the J.D. Westcott Handle Factory, and the Cherry River Paper company. In 1920, the population was 7,000. During this time there were a series of fires and floods. In 1921 a fire took down thirty-two structures, and in 1922 there was a large flood that ruined Oakford Avenue, a main road in downtown Richwood. In 1928 another fire destroyed much of what was left untouched in the first 1921 fire. In 1929 the stock market crash impacted many of the businesses in Richwood. In the 1930s coal mining jobs replaced jobs that were lost during the Great Depression, and coal remained the main employer for many people until the 1980s. In 1954 that there was another large change in the town, which was the result of a flood which damaged many houses along the Cherry River. In 2003 there was another sizable flood in Richwood. The concept of a flood control lake was proposed at this time, but the lake was never constructed, and the town is still susceptible to large floods.

According to the United States Census Bureau, as of 2017 the population of Richwood is 1906. Another important aspect to understand Richwood is its relationship to nearby communities. The main population center in Nicholas County is Summersville with approximately double the population of Richwood. A key distinction between Summersville and Richwood is that a major highway, U.S. Route 19, runs through Summersville. Also, Summersville is closer to major tourism activity in the state. Richwood is located twenty-four miles east of Summersville along Route 39, a windy road with minimal traffic. 


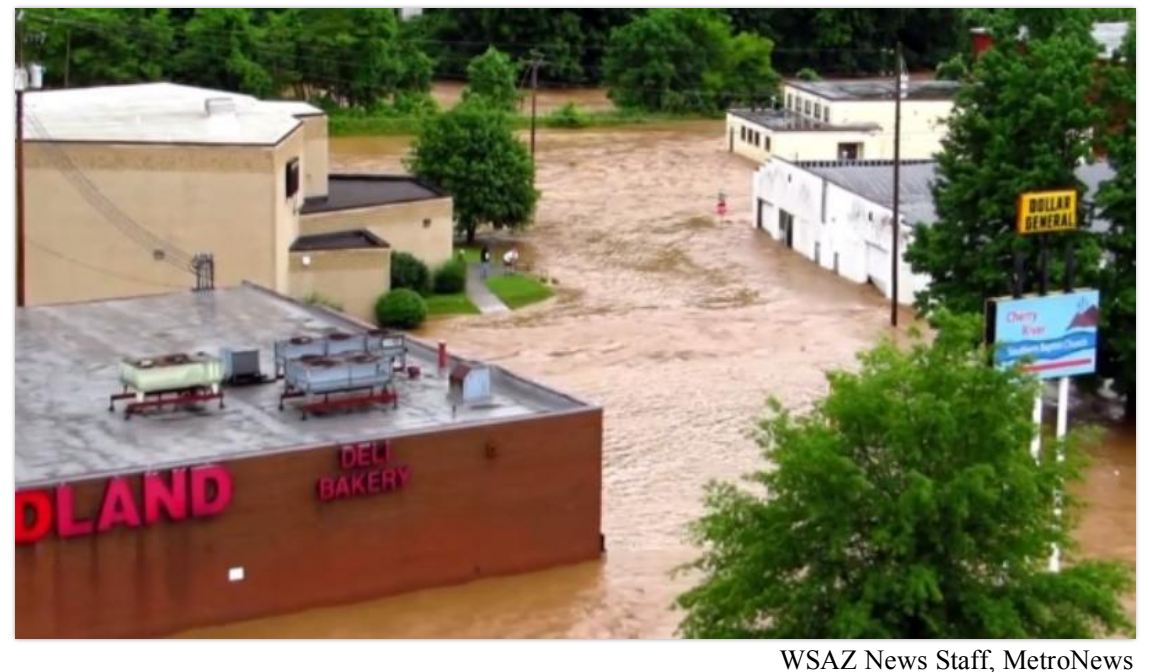

Figure 2

\section{B. The 2016 Floods}

The overall impact of the 2016 floods was devastating to the entire state of West Virginia (Kersey 2017). Twenty-six people were reported dead due to the immediate impact of the floods (Stanglin and Rice 2016), although none of these deaths occurred in Richwood. Some of the towns besides Richwood that were impacted included Clendenin and Rainelle. The Cherry River runs through Richwood, West Virginia. This is the river that flooded the town in 2016 (Figure 2). Another key factor to the flood was the water coming off the mountains surrounding Richwood. As in other communities, many people after the flood came to help citizens in need. According to interviews of Richwood citizens between 2018 and 2019, church groups and community service organizations brought the people in the community supplies and other necessities. However, the 2016 floods were particularly difficult in Richwood because they resulted in the destruction of its high school (Figure 3). This school was central to the community. Moreover, the community may not be able to have the school rebuilt as it originally was. The community also lost other buildings due to the flood, but according to my interviews, the loss of the school was considered 
the most significant, a theme that I will address at length. Another large issue that the community was left to face is a broken sewage system that it may have lost the FEMA support to replace.

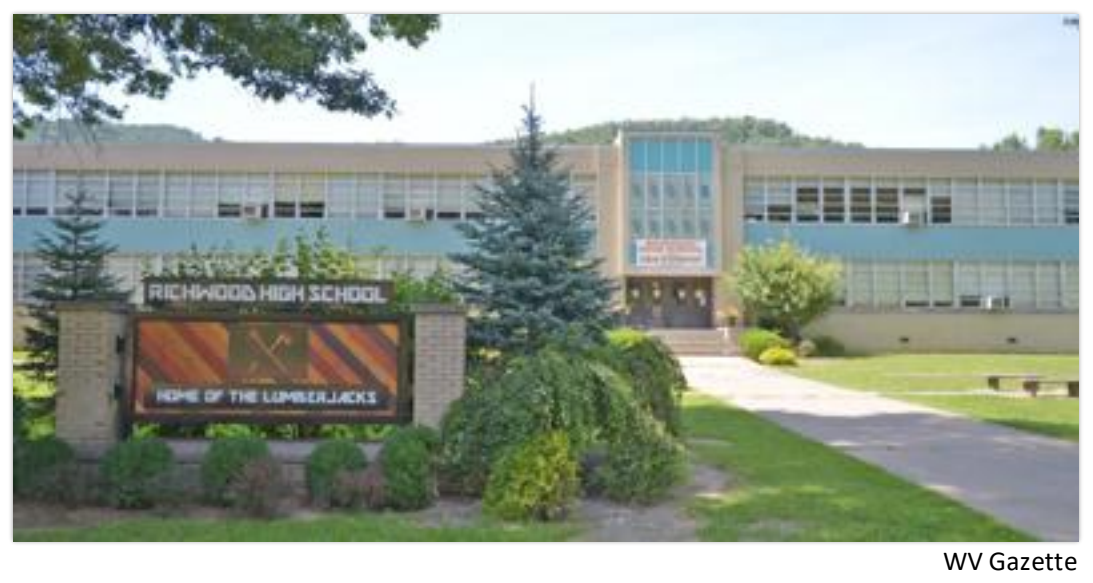

Figure 3

\section{After the Flood: Richwood High School's Uncertain Future}

I could not pursue some key topics impacting Richwood during my research because of ongoing investigations into alleged corruption regarding the misuse of FEMA funds administered after the 2016 floods. As of this writing (December 2019), there are many issues that have not been settled, and there were people who were unwilling to talk with me due to these investigations. Currently the state of West Virginia is conducting an audit to determine what happened to the FEMA funds that were allotted to Richwood for the 2016 flood recovery. Although I could not obtain many details, I elaborate on background that helps explain key aspects of the ongoing investigation.

At the center of these investigations is the future of Richwood High School (Figure 3). Although Richwood High School dates back to 1923, the main building that was impacted by the floods was built in between 1966 and 1967. Importantly, this building was located in downtown Richwood, a fact that contributes to the importance of the building to the community. According 
to eyewitness accounts provided to me by study participants, the direct impact of the floods on this building was minimal. At first Richwood residents believed that the school would just be cleaned and used again. However, the building was torn down. Then residents were concerned that the school would not be rebuilt in Richwood, using FEMA funds. At this point, the Nicholas County Board of Education decided to consolidate Richwood High School with Nicholas County High School. This would have meant that Richwood High School would not be rebuilt and Richwood would no longer have a high school. Richwood community members took the case to the West Virginia Supreme Court in 2017. They won this case because the West Virginia State Board of Education believed that rebuilding the school in Richwood was in the community's best interest (Quinn 2017). This outcome led to the belief that Richwood would get its high school rebuilt. However, after this incident the Nicholas County School Board decided it would be best to build the high school as an extension to the existing elementary school that was not impacted by the flood. I will return to this very contentious issue in the Results section. For now, it is important to note that high schoolers attend classes in FEMA pods. These pods are temporary buildings that have been placed in Craigsville, a community about fifteen minutes from Richwood.

Another important fact of local and regional governance is understanding who makes up a county school board in the state of West Virginia. According to the West Virginia Legislature website: "Each county school district shall be under the supervision and control of a county board of education, which shall be composed of five members, nominated and elected by the voters of the respective county without reference to political party affiliation. No more than two members shall be elected from the same magisterial district" (West Virginia Legislature 2019). 
Although there are members of the Nicholas County School Board that were elected to represent Richwood interests, they did not reply to my interview requests.

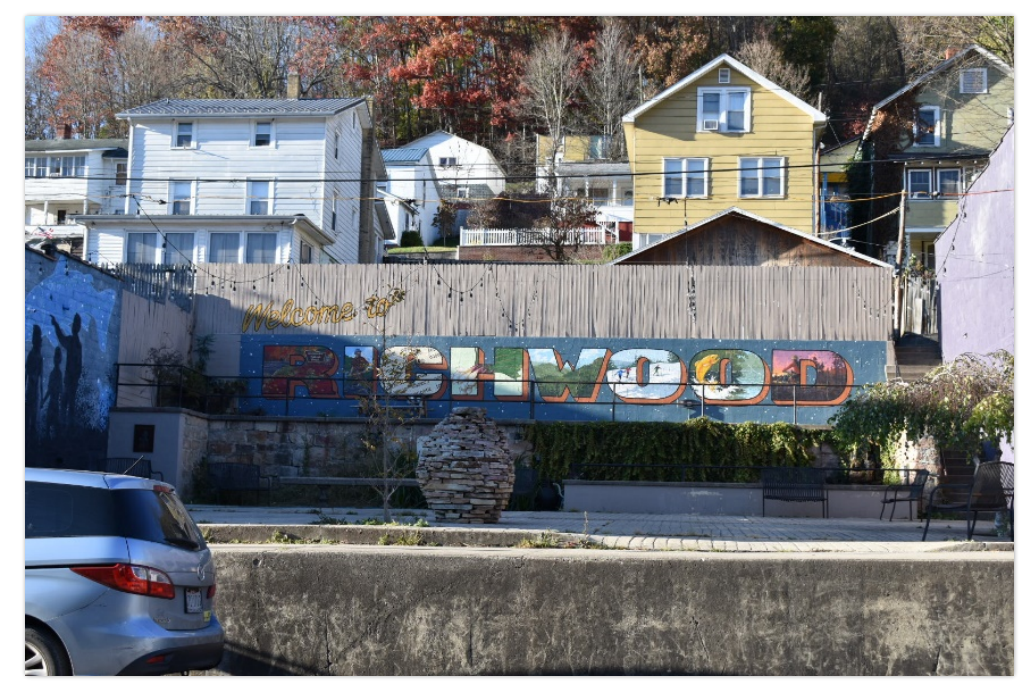

Figure 4

\section{Scenes of Life in Richwood Today}

I want to welcome the reader to the town of Richwood (Figure 4). The following notes are important to avoid thinking of the town only in terms of the flood and devastation. As I explain in more detail in the Methods section, I have a personal connection to Richwood.

The Cherry River Festival is a large festival held every year at the beginning of August. There is a fair and many reunions are held throughout town. The festival also serves as Richwood High School Homecoming every year, and will continue to do so despite the deconstruction of the school building. I have attended this festival every year of my life and watched as it has changed. When I was young the parade had many floats, but slowly the festival began to dwindle and there were fewer people at the fair and fewer floats in the parade. Recently, 2019 was a specifically special year. Although the school building is no longer in Richwood many people still came to the festival for Homecoming. There was a lantern release, fireworks, a 
parade, a fair, and a beer garden. The beer garden was a new addition in 2019 , provided by a local restaurant that opened after the 2016 flood, The Whistle Punk. The sculpture garden, which also functions as the town square, is next to The Whistle Punk. The owners were able to receive a license to use it for a beer garden during this year's festival. There was some backlash from the community because of concerns about consumption of beer outdoors; however, roughly 450 people visited the garden and there were no negative incidents. I visited this place and found it to be welcoming and a great addition to the festival. People enjoyed spending time outdoors and listening to music. The 2019 parade was also a little longer than it had been in recent years. The most important part of the parade is the Lumberjack Express (the high school marching band). This band brings a lot of pride to the community and represents the school that residents are desperately fighting to bring back to their town. When the band came down the street and was announced by the director, the cheers from the community brought tears to my eyes and gave me chills. I looked around and noticed that others were also teary-eyed, filled with emotion for all this band and Richwood High School means to the community. There is much more I will say about the band in the results section.

Throughout my research process, going to the different restaurants in Richwood was an interesting experience because each of them had their own unique feel. As of fall 2019, there are only five restaurants in the downtown area. One of them is the Moose Lodge designed for members of this organization. The diner is a place where many local people chose to eat lunch. The prices here are good and the food is homey. This was often a location people chose to meet with me for interviews over coffee. Interestingly, I had one participant that specifically wanted to meet somewhere other than the diner due to the general crowd that meets there. This person was concerned that there would be unfavorable talk concerning our interview, so we met at The Hole 
in the Wall. This is a restaurant that serves casual food such as pizza and wings. It is in the downtown area but removed from other buildings. The atmosphere here was more private than the diner and the tables were more spread out. I met with one participant at The Chill Out Grill, which is Richwood's newest restaurant. It took the place of the Dairy Queen that closed and has maintained similar fast food items. Although this restaurant is intended for fast food it turned out to be a wonderful place for an interview. The restaurant was selected because the participant worked there and felt comfortable in the environment. This was one of my longer interviews with my youngest participant.

My personal favorite restaurant is The Whistle Punk. This is the place that I would go for social evenings and lunch with my family. It is the most upscale restaurant in Richwood and has been fully operational for a little over a year. The business has wonderful food that is not necessarily traditional to the area and it is the only restaurant in town with craft beer on tap. This restaurant has a modern feel and even has a host cat named Oreo that greets their guests at the door. I first met Oreo before this restaurant was in business. I also met the Mayor here while I was having a beer with a friend one night, and it was the perfect way for me to get her card for a later interview. I also met with another participant at The Whistle Punk for an interview over dinner. The atmosphere is inviting and friendly, although, I couldn't help but notice that it is a very specific crowd that frequents this place. The prices are the highest in town. Since the food choices are not traditional to the area, although they are very good, this is another aspect that I learned impacted people's restaurant choices. A few people told me they didn't want to go there because they were not familiar with those kinds of foods. 


\section{Literature Review}

In this literature review I focus on four interrelated themes that inform my research aims and questions. These themes are the role of place in community, precarity in Appalachia and the politics of community, and devastation after a crisis and the role of hope in the aftermath. I approach "politics" from an everyday perspective as in how it impacts people's lives (Scott 2009; Valentine 2014). Questions as basic as who constitutes the community, who decides its fate, and how does a community rebuild are deeply political questions. There are also the more obviously political issues of elected officials and how these officials are making decisions that impact people's lives. For these reasons, I include a section that addresses the question of everyday politics, especially in small town rural communities.

\section{A. The Role of Place in Community}

Place is both physical and imagined. It is typically material but also aspirational, something that a person or a group of people yearn for. My study focuses on an event — the flood—and its aftermath, and how this impacted a specific town. However, place is more than just an area of land; it holds meaning to the people who live there. Three characteristics that are central to place as "meaningful" are: location, locale, and sense of place (Agnew 1987; Cresswell 2014, 12). These three aspects of place make it more than just a location marked on a map (Cresswell 2014). In the context of Richwood, it is important to consider that the town is located in space with specific coordinates, but it is also a place where things happen, and people's identities are shaped which in turn impact place. The people in the town may have different associations and attachments to the town. Place holds different meanings for people depending on who is 
interviewed. "Place is not just a thing in the world but a way of understanding the world" (Cresswell 2014, 17). Based on my research, there were several different understandings of Richwood and what would be important in the future of this place.

Similar to Cresswell, Tuan explains the meaning of place from the perspectives of those who know it and are deeply integrated in the past of a place (2014). He further suggests that to truly know a place requires spending some time there (Tuan 1975). The amount of time differs between people and what their experiences are. Tuan argues that experience is an excellent way to truly understand a place. As Tuan eloquently notes,

how mere space becomes an intensely human place is a task for the humanist geographer; it appeals to such distinctively humanistic interests as the nature of experience, the quality of the emotional bind to physical objects, and the role of concepts and symbols in the creation of place identity (Tuan 1976, 269).

In Richwood it is important to consider what experiences people have had in the town and how these experiences might alter peoples' perspectives on the town. While Tuan emphasizes the social aspects of place, geographers have not forgotten to incorporate the physical landscape and materiality in the experience and construction of place (Cresswell, 2014; DeLyser, 2015).

Doreen Massey also addresses the centrality of experience and its relation to space. She discusses the concept of "self-contained presents" $(2005,76)$ as a part of space. Those who share space but experience it differently make an impact on the space itself. When considering the future of Richwood and the lived experience of the residents it is important to consider the ways in which people experience space differently. The town itself is a space but also a place that the 
residents share. This space has changed over time and been impacted by many different events. The 2016 flood changed the experiences of the people in this space when they lost important community centers such as their high school. However, they also gained a new restaurant after the flood and the space is now being experienced differently than it was previously.

Massey's concept of space is also very important to my study because she addresses the concepts of chance and time. What is happening at any one time in a space is shaping that place. To Massey "there is always an element of chaos" $(2005,111)$ when considering space. There will be unexpected experiences that could happen at any time. What one person perceives as disorder in space another might see as a part of a routine that is very normal within that space. When conducting fieldwork in Richwood I am considering the multiple aspects of space and the impact on Richwood as a place. People's every day experiences are shaping the town and its future. Also, their imaginaries of the future shape the way the town is perceived by the individual in the present.

A focus on the role of particular landmarks is crucial for my case study, a topic geographers have addressed. Tuan notes that "to know a place is to know the past: one's own past preserved in schoolhouse, corner drug store, swimming pool and first home; the cities past enshrined in its architectural landmarks" (Tuan 1975, 164). The theme of people's particular attachment to a landmark is even more relevant for a small community where buildings like the church, the bar, or the school assume multiple roles (Valentine 2014). For example, Michael Corbett (2013) discusses the uneven privilege of exploring education and job opportunities in rural areas. He explains that many people would consider exploring these opportunities as a choice, but that is not necessarily true in some areas where this can be made more difficult. Although in this 2013 work Corbett mainly considers post-secondary education, his insights are 
still relevant to my case study when considering the difficulties some might face when attending a high school that is out of their town.

In an additional example of the centrality of a particular landmark —in this case a school — to a rural community, Jennifer Sherman and Rayna Sage describe how residents of Golden Valley, California, faced concerns about the future of their town's school. Similar to Richwood, Golden Valley is a small town that was mostly supported by the timber industry, but after the collapse of that industry in the 1990s, the future of the town became uncertain. The school in this case study was one of the last remaining social institutions in this town, and residents were concerned about any change that might occur to their school system such as consolidation, bringing in students from other communities into their town. Sherman and Sage note that the school was "a source of community cohesion" $(2011,1)$. This school was also one of the only employers left in Golden Valley, which is similar to the case of Richwood High School. "For a rural town in troubled times, education and local schools can become battlegrounds upon which the fate of the community rests..." (Sherman and Sage 2011, 1). The idea that the school holds the fate of the community echoes the phrase "the school is the heart of the community" which I heard many times during my time in Richwood, West Virginia.

Finally, I want to mention an original approach to understanding the importance of place in Richwood. It is not just places that matter but also the materiality of objects whose identities are linked to place. This is the point that Dydia DeLyser (2015) makes when she examines emotional geographies in the form of souvenir. Souvenirs are generally physical objects that are kept to remind us of a place. She collected kitsch souvenirs of the novel Ramona (DeLyser, 2015) and discusses the importance of collecting souvenirs and how it has changed through time. Some people collect items because they are of monetary value while other people's collections 
may have more of a personal value to them. As she notes, "my own collection of kitsch souvenirs of another era has become enfolded into my own personal life in intimate ways" (DeLyser 2015, 212). Also, as DeLyser notes, these objects and their circulation have a geography. These objects also impact people's attachment to place, even if a place is fictional, as in the case of the Ramona novel. Of course, Richwood is a real place. But the hope of a rebuilt and thriving Richwood may be considered a fiction to some. In Richwood, after the high school was torn down, some people collected bricks from the rubble. In the Results section I will return to the meaning of these bricks for Richwood residents. These bricks appear to be a way of remembering what once was through a physical object.

\section{B. Precarity in Appalachia and the Politics of Community}

Much scholarship on precarity, social injustice, and environmental degradation in West Virginia and the greater Appalachian region, focuses — with good reason—on how economic interests and cultural stereotypes from outside of the region are implicated in the challenges of the regions' communities. For example, in Transforming Places: Lessons from Appalachia, Stephen Fisher and Barbara Smith note how "Appalachia is an internal 'Other,' a repository of either backwardness and ignorance or, alternatively, the homespun relics of the frontier; in both cases, it is a place behind the times, against which national progress, enlightenment, and modernization might be measured" $(2012,2)$. Scholars who focus on the lived realities of people living in Appalachia challenge these stereotypes. The people, they argue, are knowledgeable about what matters in their lives and are cognizant of the environmental destruction that has taken place over past years. Shannon Bell discusses the issue of coal in her book Our Roots Run Deep as Ironweed: Appalachian Women and the Fight for Environmental Justice (2013), and how this 
issue has caused environmental problems in Appalachia. Her focus is on women as they fight for the health and the futures of their communities. Specifically in West Virginia, coal companies create a variety of environmental problems including the contamination of drinking water (Bell 2013). Bell's accounts are based on the stories of community members, highlighting their experiences from their personal point of view. For example, one participant, Maria Lambert, describes her concern about the drinking water in Boone County by observing that the filters they put in are completely black within three months (Bell 2013). Although the government knew their water wasn't safe, they did not even begin to do something about the issue for an entire year after it had been identified as a problem by the community (Bell 2013). Bell claims that "the tremendous environmental burdens the people of Central Appalachia have been forced to bear is part of a global pattern of inequality $(2013,2)$. She explains that areas where people have less political and economic power are more likely to suffer from environmental problems (Bell 2013). Appalachia is a region where those who have less economic power have been taken advantage of in many ways; however, "the injustices in Central Appalachia have not gone without resistance" (Bell 2013, 2). In fact, when speaking of Appalachia, Fisher and Smith note “the region's long tradition of individual and collective resistance to severe political, economic, and cultural oppression" $(2012,2)$.

My research in Richwood in some ways echoes these themes. However, participants identified the leadership of a neighboring town and the schoolboard of their county as the biggest culprits in the towns' troubles after the flood. Here we encounter local and regional power struggles within Appalachia that pit neighboring towns against each other. Richwood's citizens even implicate their mayor in corruption. Many participants described "greed" as being at the core of Richwood's problems. In fact, my case study contributes to understanding how local 
power struggles may seize on the excuse of a "natural disaster" to limit democracy or achieve gains for one party at the cost of another, a point that I will address in the conclusion (Klein and Smith 2008). One important contribution of my research is that I show the politics within a community cannot be examined in isolation. Even in rural West Virginia, it is important to look at how communities relate to each other and the issue of scale of politics and representation.

Scholars have noted the politics of attribution of responsibility after a disaster. For example, Olson (2008) considers the concept of blame after a disaster. His study shows how politicians aim to deflect blame and responsibility. When they do, they project blame to previous politicians, to nature, or even to the entire community as a whole. In Richwood, attribution of responsibility and blame have and continue to play a role in the aftermath of the 2016 flood. Residents of Richwood blamed a variety of different people, political figures, and institutions for their plight. Blame has an emotional register, generally represented in conversation by frustration or anger. My work looks at this emotional register.

Finally, I address the importance of agency and everyday politics, which play a role in how Richwood residents imagine and actively work towards a desired future in Richwood. Merje Kuus defines agency as "the capacity to act in a given context" $(2017,163)$. Building on the insights of feminist political geographers, Kuus highlights the spatial dimensions of agency, noting the need to "study politics within the spaces and scales that used to be considered private or apolitical" $(2017,164)$. This perspective allows for more people, particularly people who traditionally inhabit so-called private or apolitical spaces, to be considered political agents. Those who participate in informal politics are also important and contribute to the larger political system. "Attention to agents transforms our view of both agency and structure" (Kuus 2017, 165). 


\section{On Crisis and Devastation}

It is important to examine how communities react to disasters. Scholars of "disaster culture" examine the role of uncertainty that communities face after a "natural disaster" (e.g., Button, 2010; Fortun, 2001; Hoffman \& Oliver-Smith, 2002; Jones \& Murphy, 2009). This uncertainty can manifest itself in sociocultural, political, and economic ways (Button 2010). Button claims the best way to explore the nature of this uncertainty is through an ethnographic approach. "Disaster analyses must examine power relations among the various agencies and institutions involved in the event and the people affected by the disaster" (Button 2010, 16). As I will show, this focus resulted in political conversations with Richwood residents. Button further suggests that "uncertainty does not simply exist—it is produced, and the production of uncertainty can result in new political, economic, and social formations" (Button 2010, 11). Precisely how this concern is linked to uncertainty and how Richwood citizens understand the source of this uncertainty is something I sought to understand. Button further analyzes the ways that disasters are portrayed and manipulated by the media and other outside sources. This representation is something I incorporated within my research. Richwood has had news coverage on some of the issues that they have faced since the flood, and there is a very active social media page for those who live in Richwood or identify as part of their community.

Disaster never happens in a vacuum. For places that suffer multiple and repeated disasters, which is the case for Richwood, taking a long view is important. This is a point that Mike Davis makes with his work on disasters in Southern California. Although Richwood is not like Southern California, the area that Davis focuses on, still the fact remains that the 2016 flood did not come out of nowhere. Grasping this longer view also requires understanding how humans 
think about nature. Davis notes that "paranoia about nature, of course, distracts attention from the obvious fact that Los Angeles has deliberately put itself in harm's way. For generations, market-driven urbanization has transgressed environmental common-sense" (Davis 1995, 223). This insight highlights that disasters are not natural, they happen in places where humans have chosen to live. In other words, human choices contribute to the making of disasters. Davis explains that "natural" disasters are a social construct which allow people to blame nature for events that they think are out of their control, but are in fact the result of their own choices.

Other disaster scholars emphasize the need to question when a disaster community has received enough help. In Advocacy After Bhopal (2001), Fortun examines the continuation of disasters after the government exits an impacted zone. In the case of Bhopal there was a monetary settlement made after the gas leak. "Diverse individuals and organizations have entered the contest over how the Bhopal disaster should be understood" (Fortun 2001, 14). With this, Fortun emphasizes that understanding a disaster is extremely complex because all parties and individuals have their own unique point of view depending on how the disaster affected them. Like Button, Fortun uses ethnographic methods to study the aftermath of the disaster in Bhopal, including the grass-roots advocacy that followed. Fortun defines "advocacy as a performance of ethics in anticipation of the future" (Fortun 2001, 16). Fortun's definition of "advocacy as practice" informs my approach to understanding the link between the people who advocate for a cause and their hope for the future of their community. In the case of Richwood, the government money has not been used to rebuild what was lost during the 2016 flood. In both cases there is a sense that loss continues after the disaster itself.

Other scholars of disaster, like Jones and Murphy (2009), examine vulnerability within communities that have faced a "natural" disaster while also discussing cultural responses and 
resilience within these communities. They note that "resilience, even less amenable to definition, might capture the intended sense of both adaption and recovery" (Jones and Murphy 2009, 6). Resilience is very important to my study in Richwood because from the beginning I wanted to learn how the community has kept going after the flood. I also focus on the community response and the vulnerabilities of those who were involved. Jones and Murphy explain that recovery and adaptation are two aspects that are needed to better understand the long-term impact of disaster (2009). These definitions will be very important as I progress and explain the disaster Richwood has faced and the resilience of the town.

In their book Catastrophe and Culture, Hoffman and Oliver-Smith (2002) discuss vulnerability and how it speaks to disasters. To the authors, “...disasters challenge society and represent forces to which the society must adapt along a number of fronts, ecologically, socially, and ideologically" (Hoffman and Oliver-Smith 2002, 7). The authors discuss how these challenges can lead to adaptation by those who are affected by a disaster. The way Richwood is changing and adapting after the 2016 flood is an important part of my research because the changes the town has made and plans to make will have a direct effect on those who live within it. But, as Hoffman and Oliver-Smith note, "disasters unmask the nature of a society's social structure, including the ties and resilience of kinship and other alliances" (Hoffman and OliverSmith 2002, 9). This quote is particularly meaningful to my project because I investigate themes of resilience and the ties community members have to each other. Critically, these ties are also place-based, a point Hoffman and Oliver-Smith make when describing the strong attachment that people often have to place and how this attachment can be especially seen after a disaster (Hoffman and Oliver-Smith 2002). 
In a different case study, Daniel Renfrew (2018) examines the lead poisoning crisis in Uruguay and the community response. The community had a nostalgic view of the past, yet they were hopeful for a brighter future. Based on interviews, this situation appears to be very similar to how many people in Richwood feel. While I was observing and speaking with people in the town, many would talk about how things used to be. However, people also had many ideas about how they would like to revitalize Richwood. Quite a few people reminisced about the stores that used to line Main Street and commented that this is something they would love to see again in the future.

Finally, scholars caution against attributing to "nature" the causes of crises such as floods or hurricanes (Shwartz 2007; Klein and Smith 2008; Ugarte 2017). These "natural" events always need to be understood within the context of an economic and social history that often times explains the poor infrastructure of communities that suffer these crises. This context is important in order to determine the patterns of why certain groups of people (often the poor, minorities, or other marginalized groups) are affected by "crises" relative to other places (Adams 2013; Woods 2017). This context also helps explain how a "crisis" may be used by powerful actors for their economic or political gain. Naomi Klein and Neil Smith note that "natural disasters have sparked democratization projects and there's nothing wrong with that. What [they are] talking about is using a crisis to limit democracy, to declare a democracy-free zone because it's a state of emergency" (2008, 583). As Woods (2017) describes in the history of New Orleans, often times the "rebuilding" efforts after a crisis were actually an opportunity for people in power to push projects that eventually hurt and excluded vulnerable communities. These communities, such as African-American neighborhoods in New Orleans, were often not rebuilt to make space for development projects (see also Adams 2013). 


\section{Emotional Geographies of Hope}

Due to the apparent centrality of hope (or lack of it) in how Richwood residents describe the future of Richwood, my project focused on the role of emotion in shaping the geographic imaginaries of the town. Emotions also impact community motivation to carry out different projects to see the materialization of such a vision. Here I review some relevant contributions in emotional geographies that informed my work. It has already been three years since the 2016 floods in West Virginia, so my focus is on the longer-term aftermath of the event. This aftermath is not just about the physical state of the town but about how people react emotionally to the crisis and what has happened since 2016. In truth, we cannot separate the two, but I focus on the emotional register of what and how people explain how they have coped and how the make sense of the events since 2016. Also, I am interested in how emotion is recounted how Richwood residents describe the future of their community.

Although emotions are generally kept as private matter, they do play a large role in the public sphere as well. Ben Anderson and Susan Smith note that "emotional relations tend to be regarded as something apart from the economic and/or as something that is essentially private and does not substantially infuse the public/policy sphere" $(2001,2)$. They also lament the "silencing of emotion in both social research and public life" (ibid). The 2016 flood was a particularly emotional time in Richwood and the aftermath has been emotional for many people in the community. While conducting interviews I learned that many of these emotions-anger, disgust, sadness, and fear were the result of perceived acts of injustice and fueled by the concern over the town's high school. As of this writing, community residents are unsure of the future of their school and because it has been a central part of their community, they remain uncertain about the future of their community. Precisely what roles these emotions play in shaping 
people's vision for the future and the response they would like the government to take when considering the future of their school is a focal point of this project. Anderson and Smith (2001) remind us that these questions are inseparable from questions of public life.

Other scholars examine the relationship between emotion, communities, and place. Nicole Gerarda Power, Moss Edward Norman, and Kathryne Dupre (2014b) consider the role of emotional geographies among youth in a rural communities in Newfoundland and Labrador, Canada. They consider how the youth perceived their surroundings in a way associated with the loss. The researchers note that young people focused on what they did not have in their town instead of what they did have. Many of the youth also felt as though the things the generation before them made a living at were not possibilities for their futures. The researchers asked the young participants in their survey to document their lives with photos. Most participants took outdoor pictures. This was interesting because they had originally said they spent much of their time inside. This article is particularly relevant because it discusses emotional geographies and the role of perception. The initial perception of the youth in their own lives was not directly correlated with their documentation. Although I did not focus on youth in this study, the community of Richwood is also rural. Participants used photos or showed me around town to see what was gone or destroyed and not yet rebuilt. Like the rural youth of Canada, many residents focus on loss rather than on what remains.

In "The Value of Promising Spaces: Hope and Everyday Utopia in a Salvadoran Town" (2016), Alicia Sliwinski discusses hope in terms of both a nursing home and a post disaster reconstruction site (La Hermandad, El Salvador). She specifically studies "content oriented" hopes as "hopes for particular things" and how hope "express anticipations and aspirations that actively infuse peoples' conduct" (Sliwinski 2016, 432). She discusses hope in the context of 
different possible futures that people place value on and also in terms of how hope itself can change a space or the actions of people (Pérez 2016; Sliwinski 2016). This theoretical approach concerning the role of hope is valuable because it links individual action, hopes for the future, and the anticipation of places that will address people's precarity.

Ben Anderson (2017) makes further contributions to emotional geographies in his examination of hope after emergency situations. Anderson uses the coming together and small acts of kindness post-9/11 as an example of this. Although devastating events do occur, there are people who come together to help because of these events. Through this bonding is generated hope for the future. Anderson's work also contributes to emotional geographies and research that has been conducted during times of uncertainty and crisis. This is important in Richwood since people do indeed appear to have come together after the floods. Several interviews described this bonding. However, it remains to be investigated how this "coming together" is different from past community efforts and if and how it has an impact on community recovery and resilience. Hope in the terms Anderson (2006) describes it is important to geography because it impacts both space and time while also examining the relationships between people. "The disposition of hope is best defined as a relation of suspension that discloses the future as open whilst enabling a seemingly paradoxical capacity to dwell more intensely in points of divergence within encounters that diminish" (Anderson 2006, 747). Another example within the geographic literature that addresses emotion is María Pérez's work in discussing yearning and its connection to hope and the future (Pérez 2016). "Yearning is about being alive in this world, a world that includes absences, remembrances of the past, and hopes for the future" (Pérez 2016, 13). This concept is very important when considering the floods in Richwood where the people have a very specific remembrance of the past that they cherish. However, there is uncertainty when 
facing the future. During Richwood interviews I learned that many people long for a future that is in some ways similar to a remembered past. The Whistle Punk, a newly opened local restaurant is an example of community members starting a business in hopes of making these yearnings a reality. Many people discussed wanting more businesses on Main Street, which was once full of business and life. This yearning for the future could be what propels change and brings these hopes to life.

The four themes of my literature review were: the role of place in community, geographies of Appalachia and the politics of community, on crisis and devastation, emotional geographies of hope. As I will show, these themes are all deeply interrelated. All of these themes have a platial dimension and affective dimension. I will illustrate these dimensions in the results and discussion. 


\section{Methods}

\section{A. Preliminary Research}

During the summer of 2018, I conducted preliminary research visits to Richwood that helped shape the present project. During these trips I spoke to family members about their lives in the community. I also attended a free community pool day, Friday night community events, and spent time eating and observing patrons in local restaurants to get a sense of the everyday pulse of the town. Moreover, I conducted some structured interviews with community members. The goal of these interviews was to learn what the people in the community wanted for the future of their town. This experience also helped me refine the interview questions, which I describe below. This project received IRB approval.

This preliminary work pointed to how the issues with the schools have been a large problem within the community. I spoke to several community members who expressed concern about where the children would go to school and what would happen to the future of the town if there was no longer a school in the town. Another concern that I learned was the lack of businesses in the community. There is no longer a grocery store in the town or a hospital. These two basic needs came up several times, along with the concerns about the vacancies on Main Street. Many people expressed that they would like the buildings along Main Street to be occupied by local businesses. The hope is to bring more people in the town and create a better economy.

This preliminary research also included gaining background information on the Richwood Facebook page and through news sources. I was able to find news coverage and a video recording of a meeting concerning the proposal to consolidate the schools in Nicholas 
County (WSAZ News Staff 2017). This video helped me understand the intensity of the issue within this town.

\section{B. Positionality}

My positionality in this research is important because Richwood is a town that I grew up visiting frequently and it is still the town my grandparents call home. I feel as though the town itself has helped shape who I am, yet do not consider myself local. This positionality helped my research by allowing me access to community members whom I may not otherwise have been able to interview. It was also helpful in that I knew my way around town and that I was a familiar face to many participants in my study. I was originally concerned about limitations for the study arising from my positionality because of people who may have had differences in political views to my grandparents; however, after conducting the interviews I do not believe this made an impact on the direction of my research. Everyone I reached out to was willing to provide an interview. My grandparents have been very active members of the Richwood community throughout their lives. They owned multiple businesses in the town and raised their family here. This business ownership allowed them to make more money than most people in the town and there is a perceived class divide between them and the average citizen of Richwood, although I do not have direct evidence that class differences could have impacted the way people spoke with me. Before this research I was concerned that filial connections would negatively impact my capacity to interview people because the family to which one belongs means a lot in Richwood and I was concerned that not everyone would be interested in helping me because of my family history. I am not an insider to this community, but I do not feel that I am entirely an outsider either. 


\section{Case Selection}

I chose this community for my case study because of the situation it has encountered following the 2016 flood and my close connection to some of its residents. While school consolidation is not unique to Richwood, the concept of forced consolidation due to a "natural" disaster is rarely discussed. However, educational consolidation for economic reasons is very common (Finn 2015). The school is important to the foundation of the community, and residents take pride in having it located within their town. From the interviews it became clear that the community also faces other issues while in the midst of this difficult situation with the school. Richwood residents have had many problems with the distribution of FEMA funding after the 2016 flood and the repair of their broken sewage system. This research contributes to better understanding the multiple and ongoing challenges of other towns in Appalachia which face the similar ask of rebuilding after a crisis.

\section{Interviewing/Sampling}

I used a stratified random sampling method (Teddlie and Yu 2017, 79) to guide the selection of future interviewees in Richwood. The reason I chose this type of sampling is because it allowed me to speak with a variety of people in the community, and it also allowed me to speak to people who are particularly involved in the activism concerning the schools. To find these participants I not only used my connections within the town, but I also used the Richwood Facebook page to advertise this research. In addition, I used snowball sampling as a method to find interview participants. In this method I asked participants to give me the names and contact information of 
others who might be interested in participating in my research. This method proved to be "an effective way to build an exhaustive sampling frame from which you can select people at random to interview - or elect to interview all of them" (Russell 2011, 149). Using different approaches helped me to find a greater variety of interview participants. However, I am aware that there were most likely still some people who may not have been reached with these methods. Snowball sampling, in particular, also has the risk of introducing bias because people may connect the researcher to those whom they know.

During the preliminary research phase of this project, I used a structured interview guide with four questions (see Appendix A). These interviews helped guide me toward the issues that community members felt I needed to focus on. I spoke with people at community events and asked them for a short interview. These people were selected randomly and could be anyone in the community. The second set of interviews were semi-structured interviews (see Appendix B), and they were held with both specific people in the community and those who responded to my advertisements. For the longer interviews, I selected people who had been particularly active within the community, but I went beyond this and interviewed anyone who was affected by the flood and expressed interest in my advertisement. By "active" I mean participants who have been involved with court cases concerning the school, worked in groups to help others after the flood, on who have strived to bring people together for community activities after the flood.

Following WVU IRB protocols, I introduced the participants to a brief overview of the study and asked for their consent to participate. The interview guide for the semi-structured interviews consisted of twelve questions with an opportunity at the end for the participant to discuss anything related to the potential school consolidation and the 2016 flood that I may not have included within the interview guide. 
I interviewed twenty-three people (approximately fifty percent men and fifty percent women). The average age of participants was approximately forty years of age with some elderly participants and some recent high school graduates. The participants were mostly white because of the demographic makeup of the town, but I did have the opportunity to interview one African American man who lives in Richwood.

\section{E. Research Locations}

Attention to place was fundamental for this research and it manifested itself in different ways. Inwood and Martin (2008) used roving focus groups for their research on race and landscapes at the University of Georgia. The roving technique consists of going to multiple locations during an interview instead of staying stationary (Joshua Inwood and Martin 2008). I also conducted a roving interview, but not in the form of a focus group. One participant showed me around town during the interview. After we spoke for some time, she drove me to different locations around town where we were able to get out and walk. During this time, she took me on a tour of various places including a restaurant, the chamber of commerce, the heritage center, and the area where the school once stood. After our formal interview she felt that she would be able to express more to me by showing me. "Walking with interviewees ('talking whilst walking') prompts the discovery of incidents and feelings about the landscape that interview participants did not recall or find worth mentioning during the formal interview" (Anderson, 2004, cited in Inwood and Martin, 2008, p. 379). This is precisely what happened when I was undertaking my roving interview. The participant spoke much more about the town and the effects of the flood during this roving interview than she had in our formal interview alone. 
Participants wanted to meet at a variety of places. About half the interviews took place in various restaurants and the other half in the homes of the participants, except for one person who preferred to meet at their place of employment. I observed participants at multiple locations around town, many being local restaurants: The Whistle Punk, The Chill Grill, the Hole in the Wall, and the Oakford Diner. I also observed at the pool days, festivals, and events in town such as the Cherry River Festival, the Ramp Feed, and the Christmas shopping day which takes place in downtown Richwood. 


\section{Results and Discussion}

I have organized this section into three themes. They are "The School as the Heart of the Community," the Politics of Community, and Devastation and Hope. These sections are all interconnected because of the links between the 2016 flood and the loss of the school. Politics have played a large role in flood recovery and issues concerning the high school's possible reconstruction or loss. All names are pseudonyms. In these results, I highly value participants insights even when they cannot be verified. In her anthropological study of trafficking of human organs, Nancy Scheper-Hughes (2000) shows that even when rumors of kidnapping to sell organs in a black market seem exaggerated and outlandish, it is still important to take them seriously because they reflect and shape the ideas of those who believe them to be true. While my case is very different from Scheper-Hughes's work, this basic idea that rumors shape and color people's reality remains true in Richwood.

\section{Theme 1. "The School as the Heart of the Community"}

"Richwood High School is my heart and soul" - Kayla Harmen

During my interviews, the concept of the school as being at the "heart of the community" was brought up many times; however, there are different reasons why the school is important to different Richwood residents depending on who you ask. As residents' quotes illustrate below, Richwood High School (Figure 4) was a place of multiple uses and value to people in the community. It was and remains, even when closed, a "place anchor". The importance of the school echoes Tuan's argument of how key landmarks preserve the past of a place, landmarks 
that must be known to know place: "To know a place is to know the past: one's own past preserved in schoolhouse, corner drug store, swimming pool and first home; the cities past enshrined in its architectural landmarks" (Tuan 1975, 164). Many people mentioned extracurricular activities associated with the school, but the importance of the marching band was mentioned most. For the size of the school, Richwood has a remarkably large marching band, and this is something that the community takes great pride in. This was not something new to the area, but a tradition. Participants described how parents and children and even grandparents bonded over their marching band experiences. This point is a reminder of how places such as schools, churches, or public houses are so important in shaping the social relations of a community. In this case, these social relations cut across generations. Richwood residents consider the band the pride of Nicholas County and many people feel that the residents of Summersville — a nearby town also in Nicholas County—are particularly jealous of this band. The band provides wholesome activities for children in the community when there are very few other activities for them to be involved in. Another response that was common concerned the businesses. The school kept teachers and other staff employed and a steady flow of parents and children coming into and out of the town. These people supported the community. There have already been issues with this aspect of the school since the FEMA pods are not located in Richwood. FEMA pods are temporary structures built for the students to attend classes until they have a permanent school building. People mentioned the decline in business and the need for a school building in town to keep the town operating. Education for the students and the future of Richwood are also linked to this desire. Many people felt strongly about Richwood High School was important because of the kind of education that was offered to the students. It was a small school located in the center of town and the staff was aware of individual student needs. In a 
community with many students of low socio-economic status this was especially important. The teachers would put the students' basic needs first and foster an environment where people were welcome from all different kinds of backgrounds. This aspect was brought up as an important community foundation that would no longer exist if the students were removed from Richwood and placed in a larger school where their individual needs could potentially be overlooked.

I turn to Richwood residents' own words about the importance of the high school. When considering the future of the town, Vincent Peterson stated: "The school is the heart of the community and without a school it harms the community. It does not allow for recovery from the flood." Rachel Powers commented that "the school means a future for Richwood." Another participant echoed this sentiment: "The school means everything to me. It will always be a part of me, and I will always be a lumberjack. It is the heart of the community." These are very powerful statements concerning the possibilities for recovery and a future for their town and community. Alana Brown noted that "Richwood High School is the school that built me." She went on to explain that she took a brick from the school after it was demolished and that many others wanted bricks as well. I asked about the importance of the brick and she explained that "the brick is important because it is like the last photograph you have of someone. It's the last piece of a place that was dear to me. I can still hold it in my hands, and I am looking for the perfect cabinet for it." Recall DeLyser's study of the geographies of Ramona souvenirs (2015). These bricks appear to be a way of remembering what once was through a physical object. Following up on the location and meanings of these bricks provides a unique angle to my investigation. People also collect shirts and Richwood High School memorabilia as ways of remembering the school for what it was and as a way of showing their support for the future of 
the school. DeLyser's (2015) analysis help theorize the collection of these items in relation to the future of Richwood.

Caitlyn Hall expressed that "the high school was the social scene for the entire community." Since Richwood is such a rural town it is important to have social activities and events that people can come out and enjoy. Outside of school activities there are very limited resources for social based activities. According to Ben Evans "the high school brought people together no matter where they came from or what they had." I thought this was important because many children in the community are from homes with low socio-economic status and those children and their families were able to participate in high school activities that they may not otherwise be able to afford to enjoy. Residents also described how the school gave these students equal opportunities for education which was frequently mentioned because many people fear this would not be the case in a larger school outside of town. This concept certainly has some bias involved since these residents also cherished their school for other reason, however when I was speaking to residents this sentiment came through as a sincere concern for children in their town.

Recall the status of the situation on Richwood Highschool that I described as background. As of this writing, students of this high school have class in FEMA pods in a nearby community. The Nicholas County School Board's decision to rebuild Richwood High School as an annex to the elementary school is, according to multiple interviews, problematic on several fronts. First, participants claimed that it is not the same thing as getting their school back. The other issue with this idea of building onto the elementary is that it would divert FEMA funds that were intended for Richwood. Multiple participants noted that this annex plan would cost less than rebuilding the high school as a separate building, and then the majority of funds would be used to build a 
new school in Summersville. The concern here is that if this scenario plays out, families from Richwood would have the choice to send their children to either school, but the school in Richwood would not be a traditional school and would not offer the opportunities that the school in Summersville would offer. Some families might have a difficult time commuting to Summersville for this school and it would make Richwood's children's opportunities for extracurricular activities more difficult. It would also be a long bus ride for these children to attend the school in Summersville. Recall Sherman and Sage's research in Golden Valley, California (2011). They note how after the consolidation of the schools, "children from distant communities were less likely to participate in extracurricular activities, and their parents were less likely to attend school events" (Sherman and Sage 2011, 6). This problem of distance is something that multiple participants in Richwood mentioned to me as a concern that would result if Richwood High School was to be consolidated with Nicholas County High school and placed in Summersville. The children and parents might have difficulties attending events without a bus system for transportation, which many explained was an important part of attending high school.

As Corbett (2013) explains, that concept of choice may not truly apply for some who live in a rural community due to social (i.e. fewer opportunities in rural areas and family ties) and economic factors such as poverty. In the scenario that the high schools in Nicholas county were to consolidate the children from Richwood would be given the choice to attend a very small high school in their own town or a much larger high school with more opportunities in Summersville. These are the concerns that Richwood residents continue to express. What makes matters more complicated is that as of this writing, uncertainty remains for Richwood families with children. Due to the current audit there is again uncertainty about whether or not and where Richwood High School will be rebuilt. 
Recall Nancy Scheper-Hughes's work on rumors (2000). During my conversations with Richwood residents, some would site social media as their source of information regardless of the difficulty of verification of claims in these sites. Unverifiable claims are also communicated in conversations among community members. One of these claims was that the new addition to the elementary school would be made of wood and that it would either deteriorate or wash away in a future flood. Central to this claim was the idea that this new building would be far inferior to the large free-standing brick building that Richwood residents previously had for the high school. This participant explained further that this would be a very poorly built structure. He felt that the Nicholas County Board of Education wanted to build something that would not last for the purpose of spiting Richwood. Although I was unable to find any evidence supporting this claim, it is still worth taking seriously as evidence of how Richwood residents understand their plight. Critically, this claim had a strong emotional register: this participant expressed this claim with a mix of anger and sadness. Even if untrue, this claim still shapes this residents' view of a possible future for Richwood High School that would be less than desirable for the community and communicates a true concern for those who believe this to be a possible outcome.

There is another aspect that this seemingly outlandish comment about a wood structure highlights: the expectation that there will be more flooding and that Richwood, again, will not be prepared to face a future flood. (Davis 1995). Unlike the paranoia of nature the Davis describes in the case of Southern California, Richwood residents are deeply aware that disaster is not just about nature, but about human choices and actions. Critically, many study participants felt that these choices and actions unfairly impacted Richwood.

Moreover, the idea that Richwood citizens are less valued than people from nearby communities is brought forth by this rumor. Further, this sentiment alludes to people's sense of 
precarity, lack of hope for the future, and a sense of living with a threat of chaos. Echoing Massey (2005), the chaos is not just about the physical geography of Richwood, but it is also about the social element and concerns about who is making the decisions that will impact the future of their community. This example gives us an idea of how the themes of politics, community, and emotion are interrelated. I now turn to these themes in more detail.

\section{Theme 2. The Politics of Community: Who Represents Richwood?}

Unlike the topic of the school, politics in Richwood are more elusive, less defined, less evident, but constant. This topic was very important to my participants, but opinions on the issues were much more diverse and dependent on many factors. Yet, the theme of a general sense of injustice, of being the victims of a blatant wrongdoing was consistent and even dominated conversations with some participants.

One of the primary themes I noticed considering this perceived injustice had to do with children of low socioeconomic status (and an example of how the three results themes are interrelated). Participants in the community were concerned that if the school was to consolidate and become larger that these students would fall behind educationally, a theme that is important in studies on rural education (Corbett 2005; 2013; Power, Norman, and Dupré 2014). Many participants noted that the community and the school made a point of including low income children by making them feel welcome. The idea of them relocating to a larger school where the teachers didn't know the personal stories and backgrounds of their students was a concern mentioned by many of the town residents. Some participants stressed how important it is to put the students first, even before the academic curriculum because there are situations where 
helping the students on a personal level is the most important thing a teacher can do. All participants who spoke about Richwood High School teachers felt that the students were put first at their school and that this encouraged positive behavior from the students and helped them do better in school. One long-time Richwood resident spoke about his experience when he was a student with Richwood High School and how the inclusivity helped him to feel confident about going to college and chasing his dreams in higher education.

Many participants felt that the county school superintendent intentionally took the schools from them. This echoes Olson's attention to attributions of responsibility and blame (2008). This point also explains why it is important to understand the politics of the community by including actors beyond the community. The geography of rural politics cannot solely be about the community alone as if it were isolated. For example, the judgement of the superintendent with regards to Richwood High School requires that we look at regional politics. The superintendent lives in Summersville and this position represents the schools of Nicholas County. In other words, this superintendent does not represent only the interest of the Richwood community. According to some participants, the superintendent had an interest in increasing the damages claim to receive more FEMA support. Allegedly, the superintendent reported buildings other than the actual school building as part of the campus for the purpose of increasing damages. The school had been cleaned after the flood and was usable for people to stay in and eat in the cafeteria, yet it was still torn down. According to multiple participants this same person wants to create a large school with an impressive technical education center to make a name for herself. Some said that people in the Nicholas County Board of Education had a personal stake in the land of and surrounding the high school. When participants commented about the plans to build a bigger high school in Summersville, several reasoned that Summersville had always been 
jealous of Richwood and its high school band. As some participants explained to me, the Board of Education tried to throw away band uniforms, but they were unable to because a Richwood resident took them from the school and had them cleaned.

Again, this comment, even if unproven or unfounded, illustrates the need to understand community politics by situating Richwood within a broader region. In fact, Richwood residents' sense of belonging and identity is sometimes expressed by what they are not, or how they are different from other nearby communities. Class plays a role here. Participants perceive the people in Summersville as having more money and more power than those who live in Richwood. Participants sometimes referred to a history where presumably Richwood repeatedly got 'shafted' in the county. Further, many participants claimed the school was torn down for political reasons and was not as damaged as officials claimed. Residents claimed that there are places in Richwood beyond the flood plain where the school could be rebuilt. It is not clear why the Board of Education did not pursue those options that would, in the opinion of most of my participants, best suit the community's needs. Prior to the 2016 flood there was no plan for consolidation. Many residents interviewed stated that the whole situation is an incident of greed and further loss to a community that was already devastated by a "natural" disaster. Community members feel that people are trying to capitalize on the hardships that Richwood faced.

Again, I turn to the participants' own words. Anna Smith explained to me that "the hardest part was that the Board won with the school situation." Also, she noted that "FEMA was supposed to be viable," and that "the superintendent called the whole county "the community." The fact that Smith complained about this use of the term "community" illustrates how the concept is politically contested. In other words, this is an example of how community "can have multiple, contradictory political trajectories" (Fisher and Smith 2012, 6). These kinds of politics 
in the aftermath of a disaster have been noted in cases as different from Richwood as Bhopal, India, in Fortun's study (2001). "Diverse individuals and organizations have entered the contest over how the Bhopal disaster should be understood" (Fortun 2001, 14). This is similar to Richwood, with actors that are not immediately from Richwood impacting the community's recovery and even its identity. Further, Smith claimed that "the superintendent asked for FEMA to re-evaluate the school and included things that weren't even damaged. Three years later things are not taken care of and there are no schools." This situation in Richwood with the school and the Board of Education is deeply upsetting to residents. For example, another participant told me: "I am furious with them [board members, including the superintendent] taking the school down. The school was fine, well built, and clean. No water damages. I am not happy with the board members, superintendent, or the state board."

In her work on the Bhopal disaster (2001), Fortun describes "advocacy as practice" as a way to understand the link between the people who advocate for a cause and their hope for the future of their community. There have been many advocates in Richwood who have been working to keep the high school in their town. Their struggle to keep the school as it was has been ongoing since the flood in 2016. What Fortun emphasizes is that advocacy efforts involve ethics and also a sense of the future. For some key participants that already had a history of leadership and activism, the event of the flood and the high school further emboldened them to address the issues facing the community. For example, another participant wrote a series of newspaper columns where she tried to expose the elected officials who had allegedly been corrupt in some cases. She explained to me that she was part of a group that sued the Board of Education over the idea of school consolidation. This case was won by the community of Richwood. According to this participant, the Board Members became angry and decided not to 
rebuild the school as agreed and said they would "tack it on to the elementary school." She claimed that "the board conspired to tear the school down" and that "the school wasn't seriously damaged." Like Smith, she also invokes the contested nature of the concept of community by expressing "the elected officials failed our community."

\section{Theme 3. On Devastation and Hope}

Devastation and hope are key themes of this research. But again, it is important to remember that the flood cannot be thought of as "natural" or the devastation only in material terms. As Button notes, uncertainty after disaster manifests itself in sociocultural, political, and economic ways (2010). In Richwood there have been many ways that the uncertainty of the future has impacted the community. Many people in Richwood lost their homes to the flood and the town was drastically changed. Looking into the future there are varying ideas of what the town might look like. Some are hopeful that the town could come back stronger than before while others are concerned that the future is bleak for their community. The opening of some new businesses shows that some people have hope for the future. In fact, one man moved to Richwood from the West coast because he saw potential in the town. The way he described this to me was that Richwood could be anything because it is currently a "blank slate." I thought this was a unique perspective to look forward to building a future in the town. Others who have lived there for longer were sad to see their school lost and their home in a state of devastation, but many have hope that they will be able to recover with time. The loss of the school and the nursing home were recurring themes because many lost jobs and the residents of the nursing home were displaced. However, some participants still have hope that the school will be rebuilt in the town and many people are fighting to see that this happens. As the participants have repeatedly stated, 
this is more than about two buildings. This is about the social and kinship bonds of the community that depend on these places (Hoffman and Oliver-Smith 2002, 9).

Maria Ellis expressed her hopes and concerns: "Hopefully we will get help and with hard work the town can be built back. Stores will open again and other businesses. Realistically we can't do it by ourselves (rebuild the town) with no resources. Richwood won't make it." Samantha Hill claimed that "everyone in the town was effected by the flood. It brought out the best in some people and the worst in others." I thought this was important because it shows that different people have unique reactions to a "natural" disaster. She also explained that "the water and sewer system were affected and there are still people who don't have homes." Frank Williams commented specifically on the devastation while stating that the flood brought "total devastation for our town for the residents, school, businesses, waste system, and streets. Nothing was untouched." He also added that there has been "slow progress but nothing is fixed." Kelsey Bailey's story is one of loss and resilience. As she left Richwood during the 2016 flood, she saw her house split apart by the flood water. Kelsey claimed it was the scariest thing that had ever happened to her. She decided to go directly to her son's house and when she arrived a mud slide caused by the flooding hit his house. She took her three grandchildren and they were able to make it out and head towards her daughter-in-law's parents' house. On the way there, a tree uprooted and covered the car. They had to stay in their car for two days before receiving help. She lost her home and it has not yet been rebuilt but it is in the process.

However, there are people who have diverging ideas on the aftermath of the 2016 flood. Daniel Cook claimed that "the flood was for the best overall." He felt that it pushed people to do better and move forward. Thomas Young also felt there was hope for the future of Richwood. Although he is not from Richwood initially, he believes in a better future for the town. He 
explained that Richwood is a "blank slate" and that you can make an "intentional community" in these empty spaces. By "blank slate" he explained that he wants to fill buildings with businesses after these buildings have sat empty for many years. He is an entrepreneur who intends to create work opportunities for others to come and live in Richwood. This view needs to be addressed carefully. On the one hand, it could echo what Klein and Smith describe as the disaster capitalism characteristic of the "Shock Doctrine" (2008). On the other hand, the authors remind us, "natural" disasters can spark social mobilizations and improvements to people's lives (Klein and Smith 2008, 583). Even though Thomas Young is not a Richwood High School graduate, he feels that the school is an "anchor" for the community of Richwood and that it will be difficult to bring new people in to work there without a school for people's children to attend.

Rachel Powers was flooded twice. She was impacted by the flood of 2003 and then the flood of 2016. Since the house was flooded twice she and her husband are no longer able to purchase flood insurance. They have a beautiful house on property alongside the river that will have to be torn down. They initially thought that they could have their house raised but were told that they are now considered part of the flood way and flood plain. This is because of changes to a flood map that occurred after the 2016 flood. She is concerned about the future of Richwood because of the loss of the school and usable land. However, she felt that if the schools came back that there would be a rebirth and that Richwood could come back even stronger than it was before.

Sarah Carter showed concern by telling me that "the schools are still gone, and the nursing home is gone. The [nursing home] residents are still scattered, and they no longer see family members because it is too far." She worked at the nursing home and lost her job which has greatly impacted her life. When she considers the future of Richwood, she is especially 
concerned about the school, grocery store, medical care, and the loss of the lumber mill. The mill was a major employer and was lost very recently, after the flood. Brian Sickles echoed many of these concerns and added that "the future for Richwood looks very grim and that it is hard to live here as a young person." He did also express love for his town and a need for the schools to return so that the children in the community would have opportunities in their futures.

Sliwinski's (2016) work on hope and action in El Salvador was in the context of different possible futures that people put value in and in terms of how hope itself can change a space or the actions of people (Sliwinski 2016). This is very closely linked to the situation in Richwood because things are changing due to hope, at least for some. The possible future that there could be a school back in the town is one of the key components that has led to action. But that future is viewed as possible because individual people have taken action. Some key people are not just passively waiting for things to get better. They are moved to make things better. This is a hope based on action, a yearning (Pérez 2016). People from the town have fought and even hired lawyers to work towards the future they hope to see for their children. Another time that these concepts were evident while I was in Richwood are the businesses on Main Street. This is something that many people expressed hope to see in the return of businesses on this street and slowly that is becoming a reality. The street is by no means bustling as people said it once was, however, there are a few people who have started businesses such as a new restaurant and a coffee roasting shop. The community has put work into restoring the Sculpture Garden, which is a gathering area for people along Main Street. These improvements are directly linked to the hopes of people in the community.

In Richwood the community came together, specifically after the flood to help each other with basic resources such as food. An example of this would be the "red gym" which is the name 
of a basketball gym in town where they held donated goods after the flood. There were many volunteers working in the gym and anyone who needed supplies was welcome to come to the gym for their needs. Again, Tuan helps us make sense of the impact of such community involvement: "People bond when they recognize their individual powerlessness, in the face of an external challenge, which is, first and foremost, nature" (Tuan 2012, 29). This seems to be true for the community of Richwood. When the place they called home was threatened by the 2016 flood, they came together in many ways.

The themes used to organize the results are interrelated and it was extremely difficult to decide in what order to put them. The school is central to all of the themes because it came up in almost every aspect of my interviews. Many of the political issues are tied to the loss of the school. Hope for the future is also tied to the school because many participants felt that having a school is a fundamental part of building a future for their community. It was evident that the school was extremely important to the future of the town and tied into the identity of many members of the community. 


\section{Conclusions}

Building on work in emotional geographies, everyday politics, and anthropology of disaster, in this study I set out to examine how community residents cope emotionally with devastation, how they understand the causes of their plight, and more importantly, how they make sense of the future. The case study focused on Richwood, West Virginia, and the particular event at the epicenter of story is the flood of 2016. Using a mixed-methods approach that took seriously people's accounts, aspirations, and imaginaries, I show how the themes of place, politics, and hope in how Richwood residents define community and imagine its future are interrelated. A focus on the material and symbolic qualities of particular places, such as Richwood High School, as central in an outsider's ability to understand the ongoing concerns of Richwood residents. To conclude, I highlight key contributions of this study and ideas for potential future research. Appropriately, I start with Richwood High School itself.

First, the bricks of Richwood High School that are now in possession of some Richwood residents suggest that there are different ways in which people develop or strengthen a relationship to place. These bricks embody a memory, but they are also a physical manifestation of the place. This leads us to ask what kinds of attachments to place people develop, not through experiences in place, but through their physical relationship to objects of that place. For example: my mother collects rocks from all over the world. She has never been to most of these places, and yet she treasures these objects as physical extensions of these places. Specifically, her knowledge of geology helps her discern what her experience in that place would be like because these objects are traces and clues to the broader landscape. This insight is an important contribution to the creative ways in which humans develop attachment to place. 
Second, rural education scholars highlight the lack of research looking at "moral discourses and social boundaries" in the context of rural educational settings (Sherman and Sage 2011, 11). My project helps address this lack by focusing on the dilemmas Richwood residents face with the uncertainty about the school. In Richwood, people want their children to have opportunities outside of their town. For this to happen, they need to have educational opportunities, and for this to happen, they need their schools in their communities. But more than this, the school is also a place to come back to, a place of reunion. In this way, Richwood High School is a powerful community anchor that transcends the immediate educational role traditionally linked to a school. When beginning my research, I had a conversation with a faculty member who questioned the importance of the school. This was very interesting to me because where that faculty member grew up, the high school was important, but not necessarily the center of the community. In Richwood, if the school goes, so does the community. Part of acknowledging this comes from an ethnographic sensibility that informs research (McGranahan 2018), allowing participants an opportunity to share their views in an open-ended way and being with them and touring their town. This emphasizes the importance of valuing the interconnectedness of seemingly different spaces in a community.

Third, within the scholarship of Appalachia it is also very important to understand the intra-community relations and diverging paths among them. Richwood residents often referred to the diverging fates of communities just a few miles apart. This insight proposes themes for potential future research, such as which factors are conducive to local and regional collaboration and which factors hinder this collaboration, or how Richwood compares to other rural communities in Appalachia that have been impacted by similar "natural" disasters. An example of diverging paths of recovery is the story of Rainelle. Rainelle is another town that was affected 
by the 2016 flood. It is about thirty-four miles away from Richwood, which is approximately a fifty minute drive. This town is located between Fayetteville and Lewisburg, West Virginia, which are both known for tourism. I spoke with Mr. Smith who has spent most of his life in this town and learned his perspective of the flood and the aftermath. In his view, the town has used the flood to come together and rebuild a stronger community. He feels there is hope for the future of his town that it did not have prior to the flood. Neighbors came together to help each other. Moreover, community service organizations from different areas came to help with the aftermath of the flood. He believes the community gained confidence as residents saw their town being appreciated by others. Rainelle did not have the same issues as Richwood and their school was left intact after the flood. He expressed that Richwood does not seem to have the same "stirring" as Rainelle. Given the insights from my study, however, I would critically examine what is meant by "stirring." The term implies that there is some intrinsic quality of Richwood residents that would limit their capacity to recover from the flood. A comparative critical perspective would examine the historical and structural differences that differentiate the paths of recovery of different communities in Appalachia.

Fourth, learning about how these communities are rebuilding and what aspirations they have for their future would provide a broader perspective on how a "natural" disaster can impact rural Appalachian communities in different ways. While my case study highlights the phenomenon of using a "natural" disaster as a tool to advance political gains, it is also true that some residents see the aftermath of the disaster as an opportunity to build a different and more hopeful future. This is what appears to have happened in Rainelle. It is important to not forget this point which scholars of disaster capitalism acknowledge (Klein and Smith 2008). 
Finally, research such as this also has practical implications for policy. For example, this study emphasizes the importance of understanding the design and implementation of FEMA policies that are community-centered. Specifically, this case highlights the importance of considering who is making the decisions on how federal resources are being used after a disaster. 


\section{References}

Adams, V. 2013. Markets of sorrow, labors of faith: New Orleans in the wake of Katrina.

Durham, NC: Duke University Press Books.

Agnew, J. 1987. Place and politics: The geographical mediation of state and society. Boston, MA: Allen \& Unwin.

Anderson, B. 2006. Becoming and being hopeful: Towards a theory of affect. Environment and Planning D: Society and Space 24: 733-52. doi:10.1068/d393t.

—. 2017. Hope and micropolitics. Environment and Planning D: Society and Space 35 (4): 593-95. doi:10.1177/0263775817710088.

Anderson, K., and S. J. Smith. 2001. Editorial: Emotional geographies. Transactions of the Institute of British Geographers 26 (1): 7-10. doi:10.1111/1475-5661.00002.

Bell, S. E. 2013. Our roots run deep as ironweed: Appalachian women and the fight for environmental justice. Baltimore, MD: University of Illinois Press.

Button, G. 2010. Disaster culture: Knowledge and uncertainty in the wake of human and environmental catastrophe. Walnut Creek, CA: Left Coast Press, Inc.

Corbett, M. 2005. Rural education and out-migration: The case of a coastal community. Canadian Journal of Education / Revue Canadienne de l'éducation 28 (1/2): 52. doi: $10.2307 / 1602153$.

- 2013. I'm going to make sure I'm ready before I leave: The complexity of educational and mobility decision-making in a Canadian coastal community. Journal of Rural Studies 32 (October): 275-82. doi:10.1016/j.jrurstud.2013.07.006.

Cresswell, T. 2014. Place: An introduction. West Sussex, UK: John Wiley \& Sons. 
Davis, M. 1995. Los Angeles after the storm: The dialectic of ordinary disaster. Antipode 27 (3): 221-41. doi:10.1111/j.1467-8330.1995.tb00276.x.

DeLyser, D. 2015. Collecting, kitsch and the intimate geographies of social memory: A story of archival autoethnography. Transactions of the Institute of British Geographers 40 (2): 209-22. doi:10.1111/tran.12070.

Finn, S. 2015. School consolidation failed to live up to its promises. West Virginia Public Broadcasting 6 November. https://www.wvpublic.org/post/school- consolidation-failedlive-its-promises (accessed December 4, 2019).

Fisher, S. L., and B. E. Smith. 2012. Transforming places: Lessons from Appalachia. Baltimore, MD: University of Illinois Press.

Fortun, K. 2001. Advocacy after Bhopal. Chicago, IL: University of Chicago Press.

Hoffman, S., and A. Oliver-Smith, eds. 2002. Catastrophe \& culture: The anthropology of disaster. Santa Fe, NM: School of American Research Press.

Jones, E. C., and A. D. Murphy. 2009. The political economy of hazards and disasters. New York, NY: Rowman Altamira.

Inwood, J. and D. Martin. 2008. Whitewash: White privilege and racialized landscapes at the University of Georgia.” Social \& Cultural Geography 9 (4): 373-395. doi:10.1080/14649360802033882.

Kercheval, S., J. Doddridge, C. J. Faulkner, and J. J. Jacob. 1833. A history of the valley of Virginia. Winchester: S.H. Davis. http://archive.org/details/ahistoryvalleyv01jacogoog. Kersey, L. 2017. Towns hit by 2016 floods to hold events, services to mark anniversary. Charleston Gazette-Mail 18 June. https://www.wvgazettemail.com/arts_and_entertainment/events/towns-hit-by-floods-to- 
hold-events-services-to-mark/article_0143d736-f24d-5da4-9e8e-2233cb74a35e.html (accessed November 2019).

Klein, N., and N. Smith. 2008. The shock doctrine: A discussion. Environment and Planning D: Society and Space 26 (4): 582-95. doi:10.1068/d2604ks.

Kuus, M. 2017. Political geography I: Agency. Progress in Human Geography 43 (1): 163-71.

Massey, D. 2005. For space. 1 ed. London, UK: SAGE Publications Ltd.

McGranahan, C. 2018. Ethnography beyond method: The importance of an ethnographic sensibility. Sites: A Journal of Social Anthropology and Cultural Studies 15 (August): 110. doi:10.11157/sites-id373.

Olson, R. S. 2008. Toward a politics of disaster: Losses, values, agendas, and blame. In Crisis Management. Vol. 3, ed. A. Boin, 154-70. Los Angeles, CA: SAGE Publications Ltd Pérez, M. 2016. Yearnings for Guaácharo Cave: Affect, absence, and science in Venezuelan Speleology. cultural geographies 23(4): 693-714. doi:10.1177/14744740166.

Power, N. G., M. E. Norman, and K. Dupré. 2014. Rural youth and emotional geographies: How photovoice and words-alone methods tell different stories of place. Journal of Youth Studies 17 (8): 1114-29. doi:10.1080/13676261.2014.881983.

Quinn, R. 2017. WV Supreme Court upholds state's denial of Nicholas consolidation. Charleston Gazette-Mail. 10 October. https://www.wvgazettemail.com/news/education/wv-supreme-court-upholds-state-sdenial-of-nicholas-consolidation/article_901b3d72-f328-51a4-b377-b18c75191bf6.html (accessed December 4, 2019).

Renfrew, D. 2018. Life without lead: Contamination, crisis, and hope in Uruguay. Oakland, CA: University of California Press. 
Russell, B. 2011. Research methods in anthropology qualitative and quantitative approaches. 5 ed. Lanham, MD: AltaMira Press.

Scheper-Hughes, N. 2000. The global traffic in human organs. Current Anthropology 41 (2): 191-224.

Scott, S. 2009. Making sense of everyday life. Cambridge, UK: Polity.

Sherman, J., and R. Sage. 2011. Sending off all your good treasures: Rural schools, brain-drain, and community survival in the wake of economic collapse. Journal of Research and Education 26 (11): 1-14. http://jrre.vmhost.psu.edu/wpcontent/uploads/2014/02/26-11.pdf

Shwartz, S. 2007. Differential disasters. Revista: Harvard Review of Latin America. https://revista.drclas.harvard.edu/book/differential-diasters. (accessed September 2019).

Sliwinski, A. 2016. The value of promising spaces: Hope and everyday utopia in a Salvadoran town. History and Anthropology 27 (4): 430-46. doi:10.1080/02757206.2016.1207638.

Stanglin, D., and D. Rice. 2016. At least 26 dead as historic floods sweep West Virginia. USA Today 24 June. https://www.usatoday.com/story/news/2016/06/24/2-dead-floods-sweep-

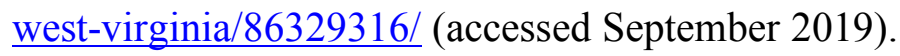

Teddlie, C., and F. Yu. 2017. Mixed methods sampling: A typology with examples. Journal of Mixed Methods Research 1 (1): 77-100. doi:10.1177/1558689806292430.

Tuan, Y. 1975. Place: an experiential perspective. Geographical Review 65 (2): 151-65. doi:10.2307/213970. 1976. Humanistic geography. Annals of the Association of American Geographers 66 (2): $266-76$. 
— 2012. Humanist geography: An individual's search for meaning. Stauton, VI: George F. Thompson Publishing.

Ugarte, R. 2017. Hurricane Maria exposes Puerto Rico's stark environmental and health inequalities. Items. October 3, 2017. https://items.ssrc.org/hurricane-maria-exposespuerto-ricos-stark-environmental-and-health-inequalities (accessed September 2019).

Valentine, G. 2014. Social geographies: Space and society. London, UK: Routledge.

West Virginia Legislature. 2019. West Virginia Code. Chapter 18: Education. http://www.wvlegislature.gov/WVCODE/code.cfm?chap=18\&art=5 (accessed November 2019).

Woods, C. 2017. Development drowned and reborn: The blues and Bourbon Restoration in postKatrina New Orleans. Athens, GA: University of Georgia Press.

WSAZ News Staff. 2017. Update: FEMA extends deadline for Nicholas County schools plans 28 December. https://www.wsaz.com/content/news/School-consolidation-approved-inNicholas-County-WVa-415622303.html (accessed July 2018). 


\section{Appendix A}

\section{Preliminary Interviews}

1. How long have you lived in Richwood?

2. What is good about living in Richwood?

3. What are the challenges about living in Richwood?

4. If you could do one thing to ensure the future of Richwood, what would it be? 


\section{Appendix B}

\section{Semi-structured Interview Guide}

1. What is your relationship to Richwood?

2. Resident, frequent visitor, or other

3. Were you impacted by the flood, if so how?

4. In your view, how did the flood impact Richwood?

5. Which of these impacts have been long lasting?

6. What do you think the future holds for Richwood?

7. What role do you see yourself playing in the shaping of that future?

8. What does Richwood High School mean to you?

9. Did you or a family member attend or plan to attend Richwood High School?

10. What was your experience with the high school?

11. What are your views on the issues concerning Richwood High School?

12. Were you an activist on the issue? If so, how? 